\title{
PENGARUH PENGGANTIAN TEPUNG IKAN DENGAN TEPUNG MAGGOT (Hermetia Illucens) DALAM RANSUM AYAM PEDAGING TERHADAP KECERNAAN KALSIUM DAN FOSFOR
}

\author{
Heince C. Pesik, J.F. Umboh*, C.A. Rahasia, Ch. S. Pontoh \\ Fakultas Peternakan Universitas Sam Ratulangi, Manado 95115
}

\begin{abstract}
ABSTRAK
Sebagai pakan, maggot dari black soldier fly (Hermetia Illucens) memiliki kandungan kalsium dan fosfor yang cukup tinggi. Masih sedikit informasi nutritif tentang kecernaan kalsium (Ca) dan fosfor $(\mathrm{P})$ ransum yang mengandung maggot. Penelitian ini bertujuan untuk mengetahui sejauh mana pengaruh penggantian tepung ikan dengan tepung maggot (Hermetia illucens) dalam ransum terhadap kecernaan kalsium dan fosfor ayam broiler. Penelitian ini menggunakan 20 ekor ayam pedaging strain CP 707 berumur enam minggu dengan berat badan berkisar antara 1300-1500 g. Penelitian ini menggunakan metode eksperimen Rancangan Acak Lengkap (RAL), yang terdiri dari 5 perlakuan dan 4 ulangan. Ransum percobaan terdiri dari 5 (lima) perlakuan, yaitu: $\mathrm{R} 0=100 \%$ tepung ikan $+0 \%$ tepung maggot; $\mathrm{R} 1=75 \%$ tepung ikan $+25 \%$ tepung maggot; $\mathrm{R} 2=50 \%$ tepung ikan $+50 \%$ tepung maggot; $\mathrm{R} 3=25 \%$ tepung ikan $+75 \%$ tepung maggot; dan $\mathrm{R} 4=0 \%$ tepung ikan + $100 \%$ tepung maggot. Kecernaan kalsium $(\mathrm{Ca})$ dan fosfor $(\mathrm{P})$ dilakukan dengan metode koleksi total. Untuk melihat sejauh mana satu perlakuan berbeda nyata dengan perlakuan lainnya, analisis dilanjutkan dengan uji Beda Nyata Jujur (BNJ). Parameter yang diukur yaitu kecernaan calcium $(\mathrm{Ca})$ dan fosfor $(\mathrm{P})$ ransum. Hasil penelitian menunjukkan bahwa semakin tinggi penggantian tepung ikan dengan tepung maggot dalam ransum, semakin tinggi kecernaan kalsium $(\mathrm{Ca})$ ransum; sedangkan penggantian tepung ikan dengan tepung maggot dalam ransum tidak memberikan pengaruh yang nyata $(\mathrm{P}>$ $0,05)$ terhadap kecernaan fosfor $(\mathrm{P})$. Dapat
\end{abstract}

*Korespondensi (corresponding author) Email : johnnyumboh@yahoo.com disimpulkan bahwa penggunaan tepung maggot (Hermetia illucens) sampai dengan 100\% menggantikan tepung ikan atau $15 \%$ dalam ransum, meningkatkan kecernaan kalsium $(\mathrm{Ca})$ dan tidak mempengaruhi kecernaan fosfor $(\mathrm{P})$ pada broiler.

Kata kunci: Tepung ikan, Tepung maggot, Kecernaan kalsium $(\mathrm{Ca})$ dan fosfor $(P)$

ABSTRACT
EFFECT OF SUBSTITUTION OF FISH
MEAL WITH MAGGOT (Hermetia Illucens)
MEAL ON CALCIUM (Ca) AND
PHOSPHORUS (P) DIGESTIBILITY OF
BROILER CHICKEN. As an animal feed,
maggot from black soldier fly (Hermetia
Illucens) has high calcium (Ca) and
phosphorus (P) content. Yet, little is known
about the digestibility of calcium (Ca) and
phosphorus (P) in the diet containing maggot.
The present study was designed to determine
the effect of substitution of fish meal with
maggot (Hermetia illucens) meal in the diets on
(Ca) and phosphorus (P) digestibility of broiler
chicken. Twenty day old chicks (DOC) CP 707
broiler chicken of about 1300-1500 g body
weight were assigned to each dietary treatment
which was replicated four times in a
Completely Randomized Design (CRD)
arrangment. The experimental diet consisted of
5 treatments and 4 replications, formulated as
follow: R0 = 100\% fish meal + 0\% maggot
meal; R1 = 75\% fish meal + 25\% maggot meal;
R2 = 50\% fish meal + 50\% maggot meal; R3 =
$25 \%$ fish meal $+75 \%$ maggot meal; and R4 =
$0 \%$ fish meal $+100 \%$ maggot meal. Calcium
(Ca) and phosphorus (P) digestibility were
calculated using total collection method.
Parameters measured were calcium (Ca) and


phosphorus $(\mathrm{P})$ digestibility. Differences were considered significant at $\mathrm{P}<0.05$. Tukey test (HSD) was employed to further analyze among treatment diferences. The results showed that calcium $(\mathrm{Ca})$ digestibility was significantly $(\mathrm{P}$ $<0,05)$ increased as the level of maggot (Hermetia Illucens) meal in the diets increased; whereas the digestibility of phosphorus $(\mathrm{P})$ was not significantly $(\mathrm{P}>0,05)$ affected by the treatments. It can be concluded utilization of maggot (Hermetia illucens) meal up to $100 \%$ replaced fish meal or $15 \%$ in the diet, inreased calcium (Ca) digestibility and did not affect phosphorus $(\mathrm{P})$ digestibility of broiler chicken.

Key words: Fish meal, Maggot (Hermetia Illucens) meal, Calcium and Phosphours digestibility

\section{PENDAHULUAN}

Selama ini, sumber protein demikian juga mineral-mineral seperti kasium dan fosfor pakan lebih mengandalkan pada tepung ikan dan kedelai. Konsekuensinya yaitu permintaan akan bahan baku pakan tersebut terus mengalami peningkatan, walaupun harganya mahal. Selain ketersediaannya yang semakin terbatas, jenis-jenis bahan pakan konvensional tersebut merupakan kebutuhan langsung dari kompetitor, yaitu manusia dan ternak. Salah satu bahan pakan yang tersedia dan belum banyak dimanfaatkan khususnya dalam susunan ransum ayam pedaging, yaitu maggot yang berasal dari lalat black soldier fly (BSF) (Hermetia illucens) (Hale, 1973). Beberapa sumber menyatakan bahwa kandungan nutrien maggot (belatung) dari lalat black soldier fly
(Hermetia illucens), antara lain: Energi $5.282 \mathrm{KkalGE} / \mathrm{kg}$, Protein kasar 42,1\%, Lemak 26\%, Kalsium 7,56\% dan Fosfor 0,9\% (Newton et al., 1977; Arango Gutierrez et al., 2004; St-Hillaire et al., 2007 dan Makkar et al., 2014). Dilaporkan, bahwa mineral kalsium yang terkandung dalam tepung maggot BSF dapat mencapai nilai kecernaan sebesar 88\% (Finke, 2012) di samping itu, memiliki kandungan fosfor tersedia (available). Sementara, tepung ikan memiliki kandungan Energi 2,820 Kkal/kg, Protein kasar 50-60\%, Lemak 9,4\%, Kalsium 5,11\%, dan Fosfor 2,88\% (Djaelani, 2012). Mengacu pada kandungan dan komposisi nutrien yang hampir sama antar tepung ikan dan tepung maggot (Hermetia illucens), perlu pengkajian lebih lanjut terhadap nilai biologis kalsium dan fosfor dari ransum ayam pedaging yang menggunakan ke dua bahan pakan tersebut, mengingat kalsium dan fosfor adalah nutrien penting yang terlibat dalam banyak proses biologis dan fungsi fisiologis tubuh (Bondari dan Sheppard, 1987), dimana mineral tersebut dibutuhkan untuk menunjang kinerja pertumbuhan dan produksi ternak unggas (Adedokun dan Adeola 2013).

Prakiraan terhadap bio-availabilitas unsur-unsur mineral dapat diperoleh dari jumlah mineral tersebut yang dapat diserap tubuh hewan. Penyerapan semu dapat digunakan dalam evaluasi terhadap unsur 
mineral tertentu dan didefinisikan sebagai, total asupan dikurangi total ekskresi fekal dari mineral tersebut (Stein et al., 2007). Nilai-nilai kecernaan kalsium dan fosfor yang digunakan secara praktis dalam formulasi pakan, kebanyakan mengacu pada nilai kecernaan semu pakan. Disebut kecernaan semu kalsium dan fosfor pakan, karena tidak dikoreksi dengan sumbersumber kalsium dan fosfor endogenous (Bronner, 1987). Beberapa laporan penelitian membuktikan, bahwa kecernaan fosfor pada unggas dipengaruhi baik oleh jumlah kalsium dan fosfor dalam ransum, maupun rasio dari kedua mineral tersebut $(\mathrm{Ca}: \mathrm{P})$, karena hubungan antagonistik antar kedua mineral tersebut dalam usus ayam broiler (Driver et al., 2005; Liu et al., 2013), sehingga perlu dipertimbangan rasio kalsium : fosfor dalam ransum.

Berdasarkan uraian di atas maka telah dilakukan suatu penelitian tentang penggantian tepung ikan dengan tepung maggot (hermetia illucens) dalam ransum ayam pedaging terhadap kecernaan kalsium dan fosfor. Penelitian ini bertujuan untuk mengetahui sejauh mana pengaruh penggantian tepung ikan dengan tepung maggot (Hermetia illucens) dalam ransum terhadap kecernaan kalsium dan fosfor ayam pedaging.

\section{MATERI DAN METODE PENELITIAN}

Penelitian ini telah dilaksanakan di kandang Fakultas Peternakan Universitas Sam Ratulangi Manado, selama 3 hari, sejak tanggal 14 Januari sampai dengan 16 Januari 2015.

Materi yang digunakan dalam penelitian ini yaitu 20 ekor ayam pedaging strain CP 707 berumur 6 (enam) minggu dengan berat badan antara 1.300-1.500 gram. Kandang yang digunakan yaitu kandang metabolis sebanyak 20 unit berukuran $25 \times 25 \times 40 \mathrm{~cm}$. Tiap unit kandang ditempatkan satu ekor ayam dan dilengkapi dengan tempat makanan dan minum.

Peralatan yang digunakan dalam penelitian ini yaitu: wadah pencampur ransum, timbangan analitik dan digital untuk menimbang bahan pakan, ternak ayam, dan alat penampungan feses dari seng plat yang dilapisi dengan aluminium foil per perlakuan. Bahan pakan yang digunakan sebagai penyusun ransum yaitu jagung kuning, dedak halus, bungkil kelapa, bungkil kedelai, tepung ikan, tepung maggot dan Top mix. Tabel 1 dan 2 menampilkan komposisi nutrien bahanbahan pakan penyusun ransum penelitian serta komposisi nutrien masing-masing perlakuan. 
Tabel 1. Komposisi Zat-zat makanan dan Energi Metabolis Bahan Pakan Penyusun Ransum Penelitian

\begin{tabular}{lcccccc}
\hline \multirow{2}{*}{ Bahan Pakan } & \multicolumn{6}{c}{ Kandungan zat-zat makanan } \\
\cline { 2 - 7 } & $\begin{array}{c}\text { Protein } \\
(\%)\end{array}$ & $\begin{array}{c}\text { S. Kasar } \\
(\%)\end{array}$ & $\begin{array}{c}\text { Lemak } \\
(\%)\end{array}$ & Ca & P & EM \\
& 9,42 & 2,15 & 5,17 & 0,22 & 0,60 & 3,182 \\
\hline Jagung Kuning & 13,2 & 6,35 & 6.07 & 0,19 & 0,73 & 2,878 \\
Dedak halus & 24,7 & 15,02 & 9,36 & 0,11 & 0,47 & 3,498 \\
Bungkil kelapa & 55,0 & 0,17 & 12,1 & 5,1 & 2,8 & 3,468 \\
Tepung ikan & 48,0 & 1.29 & 33 & 0,39 & 0,15 & 4,561 \\
Tepung Maggot & 49,0 & 2,27 & 8,26 & 0,32 & 0,58 & 3,910 \\
Tepung Kedelai & - & - & - & 5.38 & 1.44 & - \\
Top Mix & - & - & - & &
\end{tabular}

Hasil Analisis Laboratorium Kimia Makanan dan Nutrisi Ruminansia Fakultas Peternakan UNPAD, 2015

Tabel 2. Susunan Ransum Penelitian.

\begin{tabular}{|c|c|c|c|c|c|}
\hline \multirow{3}{*}{ Bahan Pakan } & \multicolumn{5}{|c|}{ Perlakuan } \\
\hline & R0 & R1 & $\mathrm{R} 2$ & R3 & $\mathrm{R} 4$ \\
\hline & \multicolumn{5}{|c|}{ Proporsi (\%) } \\
\hline Jagung kuning & 55 & 55 & 55 & 55 & 55 \\
\hline Dedak halus & 21 & 21 & 21 & 21 & 21 \\
\hline Bungkil kelapa & 3 & 3 & 3 & 3 & 3 \\
\hline Tepung kedele & 5 & 5 & 5 & 5 & 5 \\
\hline Tepung ikan & 15,0 & 11,25 & 7,5 & 3,75 & - \\
\hline Tepung maggot & - & 3,75 & 7,5 & 11,25 & 15,0 \\
\hline Mineral (Top mix) & 1 & 1 & 1 & 1 & 1 \\
\hline Total & 100 & 100 & 100 & 100 & 100 \\
\hline \multicolumn{6}{|l|}{ Komposisi nutrien $^{*}$} \\
\hline Protein $(\%)$ & 19,84 & 20,79 & 20,03 & 20,37 & 20,85 \\
\hline Lemak $(\%)$ & 5,79 & 6,21 & 6,31 & 6,35 & 6,51 \\
\hline Serat kasar (\%) & 5,21 & 5,54 & 5,25 & 5,17 & 5,48 \\
\hline $\mathrm{Ca}(\%)$ & 0,95 & 0,98 & 0,92 & 0,91 & 0,97 \\
\hline $\mathrm{P}(\%)$ & 0,53 & 0,51 & 0,59 & 0,54 & 0,56 \\
\hline $\mathrm{Ca}: \mathrm{P}$ & 1,79 & 1,92 & 1,56 & 1,69 & 1,73 \\
\hline $\mathrm{ME}(\mathrm{Kkal} / \mathrm{kg})$ & 2663 & 2892 & 3144 & 3221 & 3254 \\
\hline
\end{tabular}

Ket: Hasil Analisis Laboratorium Kimia Makanan dan Nutrisi Ruminansia, Fakultas Peternakan UNPAD, 2015.

Penelitian ini menggunakan metode eksperimen dengan Rancangan Acak lengkap (Completely Randomized Design) sesuai petunjuk Steel dan Torrie (1995), yang terdiri dari 5 perlakuan dan 4 ulangan.
Setiap ulangan terdiri dari satu ekor ayam pedaging, sehingga jumlah keseluruhan ayam pedaging yang digunakan yaitu 20 ekor. Pengaruh perlakuan ransum 
percobaan dianalisis keragamannya dan selanjutnya untuk mengetahui perbandingan antar perlakuan, analisis dilanjutkan dengan uji Beda Nyata Jujur (BNJ) sesuai petunjuk Steel and Torrie (1995).

\section{Prosedur Koleksi Data}

Sebelum pelaksanaan uji kecernaan pada minggu terakhir periode 6 minggu penelitian, ransum perlakuan sudah mulai diberikan sejak hari pertama penelitian sampai dengan saat pengumpulan data kecernaan. Ransum penelitian dibagi menjadi 2 jenis yaitu fase starter yang diberikan pada 2 minggu pertama, dilanjutkan dengan ransum fase finisher sejak memasuki minggu ketiga hingga selesai masa penelitian. Pengumpulan data ekskreta dilakukan sejak pukul 07.00 pagi sampai pukul 07.00 pagi hari berikutnya. Pengumpulan data ekskreta dilakukan dengan menggunakan metode "koleksi total" dengan cara menampung ekskreta dalam wadah penampungan dan dilakukan penimbangan ekskreta setiap kali defikasi. Sampel ekskreta segar dibersihkan dari kontaminasi kotoran atau benda-benda asing lainnya. Setelah itu, ekskreta dikeringkan di bawah sinar matahari. Untuk memperoleh berat kering ekskreta, pengeringan dilanjutkan di oven pada suhu $60^{\circ} \mathrm{C}$ selama 1 x 24 jam. Setelah dikeluarkan dari oven, ekskreta ditimbang, kemudian dicampur secara komposit untuk masing-masing perlakuan. Selanjutnya ekskreta dianalisis di laboratorium untuk memperoleh data kandungan mineral kalsium dan fosfor.

\section{Parameter yang diukur}

Untuk melihat kecernaan mineral kalsium dan Fosfor dalam ransum ayam pedaging yang mengkonsumsi tepung maggot sebagai pengganti tepung ikan dalam ransum, diukur dengan dua parameter yaitu kecernaan / retensi kalsium dan fosfor.

\section{Hipotesis Penelitian}

H0 : Substitusi tepung ikan dengan tepung maggot (Hermetia illucens) dalam ransum memberikan pengaruh tidak nyata terhadap kecernaan kalsium dan fosfor ayam pedaging

H1 : Substitusi tepung ikan dengan tepung maggot (Hermetia illucens) dalam ransum memberikan pengaruh berbeda nyata terhadap kecernaan kalsium dan fosfor ayam pedaging.

\section{HASIL DAN PEMBAHASAN}

Data hasil penelitian pengaruh penggantian tepung ikan dengan tepung maggot (Hermetia illucens) dalam ransum terhadap kecernaan kalsium dan fosfor disajikan pada Tabel 3. 
Tabel 3. Rataan kecernaan kalsium (Ca) dan fosfor $(\mathrm{P})$ pada broiler selama penelitian.

\begin{tabular}{cccccc}
\hline \multirow{2}{*}{ Uraian } & \multicolumn{5}{c}{ Perlakuan } \\
\cline { 2 - 6 } & R0 & R1 & R2 & R3 & R4 \\
\hline Kecernaan Kalsium (Ca) \% & $61,78^{\mathrm{a}}$ & $71,43^{\mathrm{bc}}$ & $67,10^{\mathrm{ab}}$ & $70,51^{\mathrm{abc}}$ & $77,93^{\mathrm{c}}$ \\
Kecernaan Fosfor (P) \% & 73,52 & 72,24 & 75,66 & 72,80 & 76,17 \\
\hline
\end{tabular}

Pengaruh Perlakuan Terhadap Kecernaan Kalsium

Angka kecernaan yang diperoleh dalam penelitian ini menunjukkan bahwa kecernaan kalsium berkisar antara 61,7877,93\%. Data pada Tabel 3 menunjukkan bahwa angka kecernaan kalsium terrendah terdapat pada perlakuan ransum yang menggunakan tepung ikan $15 \%$ tanpa penggantian dengan tepung maggot (R0), sedangkan nilai kecernaan tertinggi terdapat pada ransum dengan tingkat penggantian tepung ikan dengan tepung maggot $100 \%$ (R4). Analisis keragaman menunjukkan, bahwa penggantian tepung ikan dengan tepung maggot berpengaruh sangat nyata $(\mathrm{P}<0,01)$ terhadap kecernaan kalsium dari ransum ayam broiler. Hasil uji lanjut dengan uji beda nyata jujur (BNJ) menunjukkan, perlakuan R4 berbeda sangat nyata $(\mathrm{P}<0,01)$ lebih tinggi dari perlakuan R0, R1 dan R2, tetapi tidak berbeda nyata ( $\mathrm{P}>0,05)$ dengan perlakuan R3. Selanjutnya, perlakuan R3 berbeda sangat nyata $(\mathrm{P}<0,01)$ lebih tinggi dibanding perlakuan R0 tetapi tidak berbeda $(\mathrm{P}>0,05)$ dengan perlakuan R2 dan R1. Demikian halnya, perlakuan R1 berbeda sangat nyata $(\mathrm{P}<0,01)$ lebih tinggi dari R0, tetapi tidak berbeda $(\mathrm{P}>0,05)$ dengan $\mathrm{R} 2$. Sementara itu, antara perlakuan R2 dan R0 tidak terdapat perbedaan $(\mathrm{P}>0,05)$ pada nilai kecernaan kalsium. Angka kecernaan kalsium dalam penelitian ini menunjukkan bahwa semakin tinggi penggantian tepung ikan dengan tepung maggot dalam ransum, semakin tinggi kecernaan kalsium.

Berdasarkan rekomendasi NRC (1994), kebutuhan mineral kalsium dan fosfor dalam ransum ayam broiler umur 3 5 minggu adalah $0,90 \%$ dan $0,35 \%$ (dengan rasio $\mathrm{Ca}: \mathrm{P}=2,57: 1$ ), sementara asupan kalsium ransum percobaan dalam penelitian ini masih relatif lebih rendah dari rekomendasi tersebut, yaitu: berkisar 0,82 0,87\%. Dengan demikian, kondisi asupan kalsium ransum memenuhi pencapaian tingkat penyerapan kalsium paling aktif dalam mekanisme transpor di usus halus (duodenum dan jejunum bagian atas), yang terekspresi pada peningkatan kecernaan kalsium ransum yang menggunakan 
tepung maggot BSF. Finke (2012) melaporkan, kandungan kalsium pada tepung maggot BSF yang cukup tinggi, memiliki tingkat kecernaan mencapai $88 \%$.

Semakin meningkatnya kecernaan kalsium (Ca) dengan semakin meningkatnya penggantian tepung ikan dengan tepung maggot (Hermetia illucens) dalam ransum mengindikasikan bahwa kalsium (Ca) yang terkandung dalam tepung maggot memiliki nilai biologis yang lebih baik. Adedokun dan Adeola (2013); Rama Rao et al. (2006); mengemukakan bahwa nilai biologis merupakan predictor utama yang menentukan tinggi rendahnya nilai kecernaan suatu bahan pakan. Tepung maggot (Hermetia illucens) yang digunakan dalam penelitian ini diduga memiliki kalsium $(\mathrm{Ca})$ yang memiliki nilai biologis yang lebih baik dibanding kalsium (Ca) yang ada dalam tepung ikan. Untuk penelusuran nilai biologis tepung maggot (Hermetia illucens) pada ternak broiler perlu penelitian lebih lanjut.

\section{Pengaruh Perlakuan Terhadap}

Kecernaan Fosfor

Dari Tabel 3, dapat dilihat bahwa nilai rataan kecernaan fosfor berada pada kisaran $73,52-76,17 \%$ di mana nilai kecernaan terrendah pada perlakuan R1 atau ransum dengan penggantian tepung ikan sebesar $75 \%$ dan $25 \%$ tepung maggot, sedangkan nilai kecernaan tertinggi terdapat pada ransum dengan tingkat penggantian tepung ikan dengan tepung maggot $100 \%$ (R4).

Berdasarkan hasil analisis keragaman, ternyata penggantian tepung ikan dengan tepung maggot tidak memberikan pengaruh nyata $(\mathrm{P}>0,05)$ terhadap kecernaan fosfor pada broiler. Menurut Driver et al. (2005) dan Liu et al. (2013), kecernaan fosfor pada unggas dipengaruhi baik oleh jumlah kalsium dan fosfor dalam ransum, maupun rasio dari kedua mineral (Ca:P) tersebut, karena hubungan antagonistik antar kedua mineral dalam usus ayam broiler. Lebih lanjut Rama Rao et al. (2006) menyatakan, kelebihan kalsium dalam ransum menurunkan penyerapan fosfor disebabkan oleh pembentukan ikatan kompleks yang tidak mudah larut (insoluble) di dalam lumen usus halus. Sebaliknya, rendahnya tingkat kalsium dalam ransum dapat memicu suatu peningkatan ekskresi fosfor.

Dalam penelitian ini, rasio antara konsumsi kalsium dan fosfor (Ca:P ratio) dari semua ransum percobaan masingmasing berada pada kisaran 1,56:1 sampai 1,91:1, dimana bila dibandingkan dengan rekomendasi NRC (1994) yaitu dengan rasio $\mathrm{Ca}: \mathrm{P}=2,57: 1$, proporsi antara kaslium dan fosfor tidak berlebihan ataupun kekurangan, tetapi justru berada dalam keadaan yang seimbang. Menurut Driver et al. (2005), ransum dengan 
kalsium dan fosfor yang seimbang bisa mengakibatkan berkurangnya produksi $\left(\mathrm{Ca}_{2} \mathrm{PO}_{4}\right)$ dan ikatan kompleks kalsium-fitat dalam usus, yang akan meningkatkan jumlah fosfor (P) tersedia untuk penyerapan.di usus halus. Lagipula, tepung maggot BSF yang digunakan dalam ransum percobaan, merupakan sumber fosfor yang siap digunakan (Finke, 2012). Hal ini dapat dilihat dengan adanya peningkatan angka kecernaan fosfor $(\mathrm{P})$ ransum, seiring dengan meningkatnya penggantian tepung ikan dangan tepung maggot (Hermetia illucens), meskipun belum sampai menunjukkan perbedaan yang nyata $(\mathrm{P}>$ 0,05). Hasil penelitian ini, ternyata sejalan dengan Liu et al. (2013), yang meneliti tentang respon kecernaan fosfor $(\mathrm{P})$ dari broiler yang diberi ransum dengan perlakuan beberapa tingkat rasio kalsium : fosfor (Ca:P) dan menemukan, bahwa perlakuan-perlakuan ransum dengan rasio kalsium : fosfor antara 1,2:1 dan 2:1, ternyata menunjukkan tingkat kecernaan fosfor $(\mathrm{P})$ ransum yang tidak berbeda.

\section{KESIMPULAN}

Penggunaan tepung maggot (Hermetia illucens)sampai dengan 100\% menggantikan tepung ikan atau 15\% dalam ransum, meningkatkan kecernaan kalsium (Ca) dan tidak mempengaruhi kecernaan fosfor $(\mathrm{P})$ pada broiler.

\section{DAFTAR PUSTAKA}

Adedokun, S.A. and O. Adeola. 2013. Calcium and phosphorus digestibility: Metabolic limits. J Appl Poult Res 22 (3): 600-608. Diakses pada tanggal 28 November 2014.

Arango Gutierrez, G. P., R.A. Vergara Ruiz, H. Mejia Velez. 2004. Compositional, microbiological and protein digestibility analysis of larval meal of Hermetia illucens (Diptera:Stratiomyidae) at Angelopolis-Antioquia, Colombia. Revista - J. Nacional de Agronomia Medellin, 57 : 2491-2499. Diakses pada tanggal 7 Juli 2015.

Bondari, K. and D.C. Sheppard. 1987. Soldier fly larvae as feed in commercial fish production. J.Aquaculture 24: 103.

Bronner, F. 1987. Intestinal calcium absorption: Mechanisms and implications. J. Nutr. 117:1347-1352. Diakses pada tanggal 4 Juli 2015.

Driver, J.P., G.M. Pesti, R.I. Bakalli, and H.M. Edwards Jr. 2005. Effects of Calcium and Nonphytate Phosphorus Concentrations on Phytase Efficacy in Broiler Chicks. Poultry Science 84:1406-1417. Diakses pada tanggal 4 Agustus 2015.

Djaelani, A. 2012. Potensi Kotoran Ayam Sebagai Media Pembiakan Belatung untuk Meningkatkan Pertumbuhan dan Bobot Ayam Broiler

Finke, M.D. 2012. Complete nutrient content of four species of feeder insects. Zoo Biology 00: 1-15. Diakses pada tanggal 7 Agustus 2015 
Hale, O.M. 1973. Dried Hermetia illucens larvae (Diptera: Stratiomyidae) as a feed additive for poultry. J. $G a$. Entomol. Soc. 8:16-20.

Liu, J. B., D.W. Chen, and O. Adeola. 2013. Phosphorus digestibility response of broiler chickens to dietary calcium-to-phosphorus ratios. Poultry Science 92 :1572-1578. Diakses pada tanggal 27 Juli 2015

Makkar, H.P.S., G. Tran, V. Heuzé, and P. Ankers. 2014. State-of-the-art on use of insects as animal feed. Animal Feed Science and Technology, Vol. 197:1-33. Diakses pada tanggal 12 Juni 2015.

Newton, G. L., C.V. Booram, R.W. Barker, and O.M. Hale. 1977. Dried Hermetia illucens larvae meal as a supplement for swine. J. Anim. Sci. 44-3: 395-400. Diakses pada tanggal 14 November 2014.

NRC, 1994. Nutrien Requirements of Poultry, $\quad 9^{\text {th }}$ rev.edition. National Academy Press, Wasington, DC.
Rama Rao, S.V., M.V.L.N. Raju, M.R. Reddy. 2006. Interaction between dietary calcium and non-phytate phosphorus levels on growth. bone mineralization and mineral excretion in commercial broilers. Animal Feed Science and Technology, v.131, p.133-148. Diakses pada tanggal (19 Juli 2015)

St-Hilaire, S., K. Cranfill, M.A. McGuire, E.E. Mosley, J.K. Tomberlin, L. Newton, W. Sealey, C. Sheppard, and S. Irving. 2007. Fish offal recycling by the black soldier fly produces a foodstuff high in omega-3 fatty acids. J. World Aquacult. Soc. 38 : 309-313. Diakses pada tanggal 7 Juli 2015.

Steel, R. G. D and J.H. Torrie. 1995. Prinsip dan Prosedur Statistika: Suatu Pendekatan Biometrik. Gramedia. Jakarta.

Stein, H. H., B. Sève, M. F. Fuller, P. J. Moughan, and C. F. M. de Lange. 2007. Invited review: Amino acid bioavailability and digestibility in pig feed ingredients: Terminology and application. J. Anim. Sci. 85:172-180. Diakses pada tanggal 4 Juli 2015. 